\title{
LIMITES DA AÇÃO RESCISÓRIA ELEITORAL À LUZ DO NOVO CÓDIGO DE PROCESSO CIVIL
}

BRUNO LIMA BARBALHO

Bacharel em Direito pela Universidade Federal do Ceará (UFC), advogado e consultor jurídico com atuação em Direito Eleitoral e ex-membro e pesquisador do Centro de Estudos em Direito Constitucional (Cedic) da Faculdade de Direito da UFC.

Resumo: A ação rescisória eleitoral é um mecanismo processual introduzido pela Lei Complementar n. ${ }^{\circ} 86 / 1996$, encontrando-se disciplinada na alínea “j” do art. 22, inciso I, do Código Eleitoral, visando desconstituir decisão judicial do Tribunal Superior Eleitoral transitada em julgado que verse sobre inelegibilidade. Por outro lado, permitir que a decisão judicial possa sempre ser revista, ainda que seja caso de rescindibilidade do julgamento, causaria enorme insegurança jurídica e desestabilizaria as relações sociais, motivo pelo qual este meio impugnativo autônomo tem um prazo decadencial para ser ajuizado, sendo o limite para que os vícios existentes fiquem sanados. Nesse contexto, o presente artigo procura abordar os temas mais relevantes sobre o instituto da ação rescisória eleitoral, quais sejam hipóteses de cabimento, competência, legitimidade, prazo de ajuizamento e etc., correlacionando-os, via interpretação sistemática de efeitos extensivos, com as alterações promovidas pela Lei n. ${ }^{\circ} 13.105$, de 16 de março de 2015. Por sua vez, são discutidos pontos sensíveis quanto à aplicação das disposições do artigo 966 e seguintes do Novo Código de Processo Civil ao processo eleitoral. A metodologia aplicada foi analítica-descritiva baseada na utilização de documentos jurídicos, textos doutrinários e orientações jurisprudenciais do Tribunal Superior Eleitoral, não tendo este trabalho a finalidade de encerrar qualquer controvérsia a respeito do tema. Ao fim, de acordo com as balizas fixadas notadamente pela legislação vigente, propõese fomentar o debate acerca dos pressupostos para o ajuizamento da ação rescisória, sobretudo no que tange a excepcionalidade do cabimento, a competência, o termo de propositura e o procedimento adotado. 
Palavras-chave: Ação Rescisória Eleitoral. Natureza Jurídica. Histórico. Pressupostos. Novo Código de Processo Civil.

\section{INTRODUÇÃO}

É cediço em direito que ação rescisória visa desconstituir decisão coberta pela coisa julgada (formal ou material), permitindo, eventualmente, uma vez eliminado o vício que a contamina, o rejulgamento da causa.

Na lição de Fredie Didier Jr. e Leonardo Carneiro da Cunha (2016, p. 421):

A ação rescisória é a ação autônoma de impugnação, que tem por objetivos a desconstituição de decisão judicial transitada em julgado e, eventualmente, o rejulgamento da causa. Ela não é recurso, exatamente porque dá origem a um novo processo para impugnar a decisão judicial. A ação rescisória pressupõe a coisa julgada, contrariamente ao recurso, que impede o trânsito em julgado e mantém o estado de litispendência ou de pendência de processo. (grifos no original)

Já nas palavras de Walber de Moura Agra (2016, p. 258): “A rescisória tem a função de cercear os efeitos da coisa julgada material, acarretando um novo julgamento em razão de um vício jurídico que maculou a sentença prolatada".

Ocorre que a coisa julgada se funda, prioritariamente na necessidade social de evitar que litígios se eternizem, sendo importante instrumento para a garantia da segurança e imutabilidade das relações ao impor com definitividade a situação jurídica levada ao Poder Judiciário. Sua importância é tamanha que se encontra no rol de direitos e garantias fundamentais, prevista no art. 5, inciso XXXVI, da Constituição Federal de 1988.

Por outro lado, no processo civil eleitoral, dado os caracteres de estabilidade e rigidez, face ao calendário das eleições, o legislador não previu em um primeiro momento o cabimento da ação rescisória contra julgados revestidos pela coisa julgada, tanto é que o Código Eleitoral de 1965 não reportou sua existência.

Tal lacuna prevaleceu até 1966, isto é, trinta anos após a vigência do Código Eleitoral, momento em que foi introduzida a Ação Rescisória em 
nosso ordenamento jurídico, por meio da Lei Complementar n. ${ }^{\circ}$ 86/96, como instrumento hábil para anulação dos vícios decorrentes de julgados que versem sobre as inelegibilidades.

Acerca do assunto, Carlos Mário da Silva Velloso e Walber de Moura Agra ensinam (2016, p. 449/450):

Inicialmente, a jurisprudência e a maior parte da doutrina não admitiam a utilização da ação em sede de Direito Eleitoral, seja devido à ausência de presunção legal, seja em decorrência da segurança e da celeridade do processo eleitoral. Nesse sentido, até o início do ano de 1966, o posicionamento de nossa doutrina e jurisprudência era no sentido de que o efeito da coisa julgada era absoluto, inexistindo qualquer possibilidade de se ingressar com ação rescisória no processo eleitoral, contrariando a sistemática encontrada em outros ramos do Direito.

A Lei Complementar n. ${ }^{\circ}$ 86/96, entretanto, acrescentou no Código Eleitoral a alínea "j" do inciso I, atribuindo ao Tribunal Superior Eleitoral a competência para processar e julgar a ação rescisória, nos casos de inelegibilidade, desde que intentada dentro de cento e vinte dias de decisão irrecorrível de mérito...

Nesse enfoque, faz-se oportuno destacar os ensinamentos de Marcílio Nunes Medeiros (2017, p. 342) sobre os efeitos e a natureza jurídica desta ação eleitoral:

Como no processo civil, na ação rescisória eleitoral o autor deve cumular o pedido de rescisão do julgado com o pedido de rejulgamento da causa. Julgada procedente a ação, o TSE emite provimento contrário àquele objeto da rescisória, afastando a inelegibilidade em um primeiro momento e, em seguida, restabelecendo o mandato ou a diplomação ou deferindo o registro de candidatura do autor da ação rescisória, conforme o caso.

Com efeito, entende-se que referida lei complementar tutelou a prática regular dos direitos políticos negativos, ao acrescentar a alínea “j” ao art. 22, I, do Código Eleitoral, que estabelece a competência originária do Tribunal Superior Eleitoral (TSE) nos seguintes termos: "processar e julgar originariamente: a ação rescisória, nos casos de inelegibilidade, desde que intentada dentro de cento e vinte dias de decisão irrecorrível, possibilitandose o exercício do mandato eletivo até o seu trânsito em julgado"1.

\footnotetext{
1 Segundo José Jairo Gomes (2016, p. 253): “A ação rescisória eleitoral é prevista no
} 


\section{HIPÓTESES DE CABIMENTO}

No âmbito do Direito Eleitoral, admite-se, por opção legislativa, a propositura de ação rescisória tão somente em casos de pronunciamento do Tribunal Superior Eleitoral, no qual se tenha declarado ou reconhecido qualquer das hipóteses de inelegibilidade.

De acordo com a definição de José Jairo Gomes (2016, p. 255):

A demanda deve ter por objeto a rescisão de decisão do próprio Tribunal Superior Eleitoral, proferida no âmbito de sua competência originária ou recursal. Destarte, esse sodalício não detém competência para rescindir julgado de Tribunal Regional, tampouco de juiz eleitoral de $1^{\circ}$ grau.

$[\ldots]$

Quanto à matéria impugnável, a enfocada alínea "j” estabelece expressamente que a decisão cujo desfazimento se pleiteia deve versar sobre inelegibilidade. Assim, há mister que se tenha declarado ou constituído inelegibilidade.

Já nos dizeres de Carlos Mário da Silva Velloso e Walber de Moura Agra (2016, p. 450):

Ela apenas se configura como remédio cabível nos casos de declaração de inelegibilidade, por sua vez, consubstanciados na LC n. ${ }^{\circ}$ 64/90 (Lei das Inelegibilidades). Em qualquer outra matéria, obstaculizase sua impetração, haja vista a ausência de sustentação legal. Ou seja, em matéria eleitoral, somente caberá ação rescisória quando o tema em debate versar a respeito de inelegibilidades, sancionadas de acordo com mandamento estipulado na Constituição Federal ou em lei complementar.

Por sua vez, a jurisprudência recente do Tribunal Superior Eleitoral, ao interpretar a norma, restringe severamente o objeto da ação rescisória, vejamos:

art. 22, I, j, do Código Eleitoral (incluído pela LC n. ${ }^{\circ}$ 86/96), que trata da competência do Tribunal Superior Eleitoral. Originalmente, essa alínea continha a seguinte redação: “j) a ação rescisória, nos casos de inelegibilidade, desde que intentada dentro de cento e vinte dias de decisão irrecorrível, possibilitando-se o exercício do mandato eletivo até o seu trânsito em julgado". Todavia, ao decidir a Ação Direta de Inconstitucionalidade ADI n. ${ }^{\circ}$ 1.459-5-DJ 7-5-1999-, o Supremo Tribunal Federal declarou a inconstitucionalidade da expressão "possibilitando-se o exercício do mandato eletivo até o seu trânsito em julgado”. Assim, atualmente só a primeira parte encontra-se em vigor”. 
AGRAVO REGIMENTAL EM AÇÃO RESCISÓRIA. PRESTAÇÃO DE CONTAS. AÇÃO RESCISÓRIA. NÃO CABIMENTO. ACÓRDÃO RESCINDENDO QUE NÃO ADENTROU NO MÉRITO DA INELEGIBILIDADE. INTELIGÊNCIA DO ART. 22, INCISO I, ALÍNEA "J” DO CE. AÇÃO RESCISÓRIA À QUAL SE NEGOU SEGUIMENTO. INCIDÊNCIA DA SÚMULA 33 DO TSE. AGRAVO REGIMENTAL NÃO PROVIDO.

1. Nos termos da Súmula 33 do TSE, somente é cabível Ação Rescisória de decisões do TSE que versem sobre a incidência de causa de inelegibilidade.

2. O julgado objeto da presente Ação Rescisória foi proferido por esta Corte nos autos da Prestação de Contas 44-34.2015.6.02.0000 e não conheceu do Recurso Especial, uma vez que se encontrava apócrifo.

3. Agravo Regimental ao qual se nega provimento.

(TSE, AgRg em AR 54253, Rel. Min. Napoleão Nunes Maia Filho, j. em 09.03.2017, DJE de 30.03.2017).

Ocorre que o artigo 22, inciso I, alínea “j” do Código Eleitoral, não indicou os fundamentos que podem embasar o juízo rescindente, o que justifica per se, diante da ausência de previsão legal, o entendimento doutrinário de que os fatos autorizativos do cabimento da ação rescisória são também os preceituados no art. 966 do Novo Código de Processo Civil (NCPC).

Seguindo esse viés, Jaime Barreiros Neto (2016, p. 403) afirma que:

São pressupostos da Ação Rescisória Eleitoral a existência de decisão transitada em julgado versando sobre matéria de inelegibilidade, a observância do prazo decadencial de 120 dias para a sua propositura e o enquadramento em uma das seguintes hipóteses previstas no art. 966 do Novo Código de Processo Civil (Lei n. ${ }^{\circ}$ 13.105/15).

Com efeito, defende-se que é imprescindível para o cabimento da ação rescisória eleitoral a ocorrência de uma hipótese de inelegibilidade e um dos fatos enumerados no art. 966 do NCPC, quais sejam: decisão produto de prevaricação, concussão ou corrupção, impedimento do magistrado, incompetência absoluta do juízo, dolo ou coação da parte vencedora em detrimento da parte vencida, simulação ou colusão das partes, ofensa à coisa julgada, manifesta violação a norma jurídica, prova falsa, prova nova e erro de fato. 
Não é à toa que há um Projeto de Lei Complementar do Senador Sérgio de Souza (PLS n. ${ }^{\circ}$ 134/2012) em trâmite que pretende ampliar o uso da ação rescisória, inserindo o art. 282-A no Código Eleitoral, cujo teor segue adiante:

Art. 282-A. É cabível ação rescisória em face de decisão de mérito de órgão da Justiça Eleitoral transitada em julgado, quando:

I- restar demonstrada a prevaricação, concussão, corrupção, suspeição ou o impedimento de juiz que tenha participado da decisão;

II- a decisão resultar de dolo da parte vencedora em detrimento da parte vencida, ou de colusão entre as partes, a fim de fraudar a lei;

III- a decisão ofender coisa julgada;

IV- houver violação de lei ou da Constituição Federal;

$\mathrm{V}$ - a decisão se fundar em prova cuja falsidade tenha sido apurada em processo criminal ou seja provada na própria ação rescisória;

VI- depois da decisão, a parte obtiver documento novo, cuja existência ignorava, ou de que não pode fazer uso, capaz, por si só, de lhe assegurar pronunciamento favorável;

VII- a decisão estiver fundada em erro de fato, resultante de atos ou de documentos da causa.

$\int 1^{\circ}$. Há erro quando a decisão admitir um fato inexistente ou quando considerar inexistente um fato efetivamente ocorrido.

$\int 2^{\circ}$. É indispensável, num como noutro caso, que não tenha havido controvérsia, nem pronunciamento judicial sobre o fato.

Em comentários ao dispositivo supra, contextualizando com o Novo Código de Processo Civil, Pedro Henrique Távora Niess ensina que (2016, p. 351):

Em relação ao art. 485 do Código de Processo Civil de 1973, notamse as seguintes diferenças mais chamativas: o caput do art. 282-A do direito projetado, tal como o do art. 966 do CPC/2015 (ver também o seu $\int 2^{\circ}$ e o art. 502), fala em decisão de mérito, não em sentença; o inciso I do art. 282-A do Projeto reúne as previsões dos incisos I e II do art. 485 do CPC/1973 e do art. 966 do CPC/2015, excluindo a decisão proferida por juiz absolutamente incompetente e incluindo a suspeição, o que merece ser repensado; o inciso $\mathrm{V}$ do art. 485 do CPC/1973 fala em violação a literal disposição de lei e o inciso IV do art. 282-A do Projeto em violação da lei ou da Constituição Federal, com o que lhe dá, ao que parece, a feição de recurso, enquanto o novo CPC refere-se à manifesta violação de norma jurídica; [...] o Projeto, na esteira do CPC/1973, prevê a hipótese de obtenção de documento novo após a decisão, capaz, por si, de assegurar pronunciamento favorável ao autor da rescisória, ao passo que o CPC/2015, no inciso VII do art. 966, consagra a hipótese de obter o autor, posteriormente ao trânsito em julgado, prova nova, também exigindo, como os outros citados diplomas, a ignorância, por ele, da existência dessa prova com 
aptidão para afiançar-lhe decisão favorável ou de que dela não pôde fazer uso. Quanto aos $\$ \mathbb{S} 1^{\circ}$ e $2^{\circ}$, o art. 282-A do Projeto, substituindo sentença, por decisão, repete os $\iint 1^{\circ}$ e $2^{\circ}$ do art. 485 , do CPC $/ 1973$ que lhe serviu de modelo, e o art. 966 do CPC/2015, agrupando as regras, dispõe, mais apropriadamente: " $\int 1^{\circ}$. Há erro de fato quando a decisão rescindenda admitir fato inexistente ou quando considerar inexistente fato efetivamente ocorrido, sendo indispensável, em ambos os casos, que o fato não represente ponto controvertido sobre o qual o juiz deveria ter se pronunciado." (grifos no original)

Em verdade, a finalidade dos operadores do direito é estender o raio de ação da rescisória eleitoral, incluindo os pressupostos especificados no art. 966 do NCPC, a abranger decisões de mérito dos Tribunais Regionais Eleitorais, ainda que não seja o entendimento jurisprudencial firmado hodiernamente na Suprema Corte Eleitoral.

\subsection{CASOS DE INELEGIBILIDADE E A JURISPRUDÊNCIA DO TSE}

Conforme restou destacado, o cabimento da Ação Rescisória está vinculado aos casos de decretação de inelegibilidade via acórdão proveniente do Tribunal Superior Eleitoral que tenha transitado em julgado.

Assim, por questão lógica, é inadmissível a propositura de ação rescisória para desconstituir acórdão de Tribunal Regional Eleitoral ou acórdão do Tribunal Superior Eleitoral em que não aborde hipótese de inelegibilidade ${ }^{2}$.

Sob esse prisma, dada a taxatividade do texto legal, não há que se falar também em ação rescisória contra decisão condenatória às multas por divulgação de pesquisa eleitoral e por conduta vedada ao agente público.

Feitas tais considerações, vale frisar que o TSE tem entendimento restritivo acerca do cabimento da ação rescisória, afastando sua incidência quando a matéria envolve condição de elegibilidade, como se vê pelo teor da ementa colacionada abaixo:

2 AGRAVO REGIMENTAL. AÇÃO RESCISÓRIA. ACÓRDÃO DE TRE. MATÉRIA PENAL. DESCABIMENTO. DECISÃO AGRAVADA. FUNDAMENTOS NÃO INFIRMADOS. AGRAVO REGIMENTAL DESPROVIDO. 1. No âmbito da Justiça Eleitoral, a ação rescisória só é cabível para desconstituir acórdãos do TSE que contenham declaração de inelegibilidade (art. 22, I, j, do Código Eleitoral). Precedentes. 2. Agravo regimental desprovido. (TSE, AR 179722, Rel. Min. José Antônio Dias Toffoli, j. em 04.09.2012, DJe de 24.09.2012) 
ELEIÇÕES 2012. AGRAVO REGIMENTAL NA AÇÃO RESCISÓRIA. DESCABIMENTO. CAUSA PETENDI QUE NÃO VERSA SOBRE INELEGIBILIDADE. DESCABIMENTO. ART. 22, I, J, DO CÓDIGO ELEITORAL. VIOLAÇÃO AO ART. 15 DA CONSTITUIÇÃO DA REPÚBLICA. INOVAÇÃO RECURSAL. INADMISSIBILIDADE. MANUTENÇÃO DA DECISÃO FUSTIGADA POR SEUS PRÓPRIOS FUNDAMENTOS. DESPROVIMENTO.

1. O princípio da tutela jurisdicional efetiva, ex vi do art. $5^{\circ}, \mathrm{XXXV}$, não é ultrajado quando o Relator do processo, mediante decisum monocrático, nega seguimento à pretensão do Autor, ancorado na manifesta inadmissibilidade, improcedência, prejudicialidade ou quando o aresto esteja em confronto com súmula ou com jurisprudência dominante deste Tribunal Superior Eleitoral, do Supremo Tribunal Federal ou de Tribunal Superior, nos termos do art. 36, \ $6^{\circ}$, do TSE.

2. A ação rescisória, no âmbito desta Justiça Especializada, revela-se medida excepcional, destinada a rescindir decisão judicial definitiva que assenta a restrição ao ius honorum (inelegibilidade) dentro do prazo decadencial de 120 (cento e vinte) dias, sendo defeso proceder à interpretacãa extensiva de suas hipóteses de cabimento.

3. No caso sub examine, o Autor pretende rescindir acórdão que assentou a ausência de condição de elegibilidade (i.e., falta de quitação eleitoral), e não bipóteses de inelegibilidade, circunstância que, na esteira da remansosa jurisprudencia desta Corte Superior Eleitoral, não autoriza a propositura da ação rescisória. - grifos nossos

4. Agravo regimental desprovido.

(TSE, AR 52840/MG, Rel. Min. Luiz Fux, j. em 24.03.2015, DJE de 02/10/2015)

Em decorrência disso, não se admite, de igual modo, ação rescisória contra acórdão que envolve a ausência de quitação eleitoral ${ }^{3}$ e ausência de filiação partidária ${ }^{4}$.

${ }^{3}$ AGRAVO REGIMENTAL. AÇÃO RESCISÓRIA. REGISTRO DE CANDIDATURA. CONTAS DE CAMPANHA NÃO PRESTADAS. AUSÊNCIA DE QUITAÇÃO ELEITORAL. CONDIÇÃO DE ELEGIBILIDADE. INADMISSIBILIDADE. NÃO PROVIMENTO. 1. De acordo com a jurisprudência desta c. Corte Superior, a competência do Tribunal Superior Eleitoral em sede de ação rescisória limita-se à revisão de seus próprios julgados que tenham analisado o mérito de questões relativas à inelegibilidade (art. 14, $\iint 4^{\circ}, 7^{\circ}$ e $9^{\circ} \mathrm{da} C F / 88$ e LC 64/90). Precedente: AR 645-02/PE, Rel. Min. Henrique Neves, DJe de 13.8.2012. 2. No caso, a presente ação não merece trânsito, pois o acórdão rescindendo versa sobre a ausência de condição de elegibilidade que decorre da falta de quitação eleitoral pela não apresentação das contas de campanha no pleito de 2010 (art. 11, $\int 7^{\circ}$, da Lei 9.504/97). 3. Agravo regimental não provido. (TSE, AR 16927/SP, Rel. Min. José de Castro Meira, j. em 06.08.2013, DJe de 28.08.2013).

${ }^{4}$ Ação rescisória. Acórdão de Tribunal Regional Eleitoral. Filiação partidária. 1. A jurisprudência é pacífica no sentido de que somente cabe ação rescisória para 
Com efeito, a jurisprudência da Suprema Corte Eleitoral, ao interpretar a norma estatuída no artigo 22, inciso I, alínea “j”, do CE, é extremamente restritiva e tem exigido que o aresto rescindendo tenha reconhecido ou declarado a inelegibilidade ${ }^{5}$.

Inobstante, parte da doutrina entende que cabe a ação rescisória na hipótese de ausência de condição de elegibilidade, consoante asseveram Carlos Mário da Silva Velloso e Walber de Moura Agra (2016, p. 450/451):

...ela é igualmente cabível no caso de sentença transitada em julgado devido a ausência de condição de elegibilidade, em razão de sua natureza constitucional e do fato de representar uma diminuição nas prerrogativas de cidadania do eleitor. Tanto as inelegibilidades quanto a ausência das condições de elegibilidade cerceiam a elegibilidade do cidadão. Se a ação rescisória é pertinente com relação às inelegibilidades, das quais algumas ostentam status infraconstitucional, não há motivação para que ela também não seja pertinente para as condições de elegibilidade, que ostentam status constitucional. (grifos no original)

É de suma importância o registro acima, porque, do contrário, e se for seguida ao pé da letra a jurisprudência do TSE, seríamos forçados a

rescindir acórdãos do Tribunal Superior Eleitoral, não se admitindo seu ajuizamento para desconstituir acórdão de Tribunal Regional Eleitoral. 2. A ação rescisória só é cabível em casos que versem sobre causa de inelegibilidade, e não naqueles atinentes a condição de elegibilidade. 3. Agravo regimental não provido. (TSE, AR 295294/PR, Rel. Min. Arnaldo Versiani Leite Soares, j. em 06.10.2010, DJe de 12.11.2010).

5 AGRAVO REGIMENTAL EM AÇÃO RESCISÓRIA. AUSÊNCIA DE EXCEPCIONALIDADE A JUSTIFICAR O MANEJO DO INSTRUMENTO PROCESSUAL. CAUSA PETENDI QUE NÃO VERSA SOBRE INELEGIBILIDADE. DESCABIMENTO. ART. 22, I, J, DO CÓDIGO ELEITORAL. DECISÃO MANTIDA POR SEUS PRÓPRIOS FUNDAMENTOS. DESPROVIMENTO. 1. A ação rescisória, no âmbito da Justiça Eleitoral, tem objeto restrito (i.e., versa apenas sobre causas relativas à declaração de inelegibilidade), ex vi do art. 22, I, j, do Código Eleitoral. 2. In casu, neguei seguimento à ação rescisória, assentando não estar preenchida a hipótese do seu cabimento, porquanto a decisão rescindenda não declarou qualquer inelegibilidade, já que negou provimento a recurso ordinário em mandado de segurança, por meio do qual se objetivava a exclusão - do cadastro do então impetrante - de anotação de suspensão dos direitos políticos decorrente de condenação criminal, considerando ter sido favorecido por indulto presidencial. 3. A simples reiteração de argumentos já analisados na decisão agravada e o reforço de alguns pontos, sem que haja no agravo regimental qualquer elemento novo apto a infirmá-la, atraem a incidência do Enunciado da Súmula n. ${ }^{\circ} 182$ do STJ. 4. Decisão agravada mantida por seus próprios fundamentos. 5. Agravo regimental desprovido. (TSE, AR 31852/RJ, Rel. Min. Luiz Fux, j. em 16.06.2016, DJe de 26.08.2016). 
concluir que a expressão legal "nos casos de inelegibilidade" não abrange, em hipótese alguma, a declaração de elegibilidade.

De fato, não há que se prestigiar tal interpretação restritiva, pois a própria Lei Complementar n. ${ }^{\circ}$ 64/90 trata de forma uniforme os institutos da inelegibilidade e da elegibilidade, o que per se não justifica qualquer distinção para efeito de cabimento da ação rescisória.

\subsection{FUNDAMENTOS DA AÇÃO RESCISÓRIA ELEITORAL}

Os fundamentos para ajuizamento da ação rescisória eleitoral são também aqueles elencados no art. 966, do Novo Código de Processo Civil, quer dizer, a decisão rescindida deve versar sobre inelegibilidade e apresentar um dos vícios indicados no aludido dispositivo ${ }^{6}$.

Nas palavras de José Jairo Gomes (2016, p. 253/254):

${ }^{6}$ RECURSO ELEITORAL. QUERELA NULLITATIS INSANABILIS. DECISÃO PROFERIDA EM AIJE. ALEGAÇÃO DE FALSIDADE DE PROVA TESTEMUNHAL. INADEQUAÇÃO DA VIA ELEITA. FALTA DE INTERESSE PROCESSUAL. EXTINÇÃO DO PROCESSO SEM RESOLUÇÃO DO MÉRITO. DESPROVIMENTO DO RECURSO. 1. A querela nullitatis insanabilis, ação declaratória de nulidade insanável, é admissível no nosso ordenamento jurídico nos casos de citação nula ou ausência de citação aliada à revelia, objetivando a declaração de nulidade da sentença proferida em tais processos. 2. O caso em exame não se enquadra em tais hipóteses, visto que o recorrente busca a anulação da decisão transitada em julgado em ação de investigação judicial eleitoral alegando a falsidade de prova testemunhal produzida naquele processo. 3. A falsidade da prova na qual se fundou a decisão é uma das situações que autorizam o ajuizamento da ação rescisória, nos termos do art. 966 do CPC. Destarte, a hipótese é de rescisão da decisão transitada em julgado, e não de anulação, como pretende o recorrente, tratandose, portanto, de vício rescisório (que dá margem ao ajuizamento da ação rescisória), e não de vício transrescisório (que permite o manejo da ação declaratória de nulidade), como se afirma na peça recursal. 4. Em matéria eleitoral, a ação rescisória é prevista exclusivamente no art. 22, I, “j”, do Código Eleitoral, segundo o qual compete ao TSE processar e julgar originariamente a ação rescisória nos casos de inelegibilidade, desde que intentada dentro de 120 dias de decisão irrecorrível. 5. Ao restringir o cabimento da ação rescisória à hipótese e ao prazo previstos no supracitado dispositivo, a intenção do legislador é garantir maior segurança jurídica nas questões decididas pela Justiça Eleitoral, evitando que, fora daquela hipótese específica ou após o prazo ali previsto, as decisões transitadas em julgado proferidas por esta Justiça especializada estejam abertas a rediscussão. 6. Desprovimento do recurso. (TRE-RJ, Recurso Eleitoral n 4654, Rel. Des. Marco José Mattos Couto, j. em 29.09.2016, DJe de 07.10.2016). 
O aludido do art. 22, I, “j”, do CE não indicou os fundamentos que podem embasar o juízo rescindente. Face à omissão legal, aceita-se a aplicação por analogia - e com as adaptações necessárias - das hipóteses arroladas no artigo 966 do CPC, segundo o qual a decisão de mérito, transitada em julgado, pode ser rescindida quando:

"I - se verificar que foi proferida por força de prevaricação, concussão ou corrupção do juiz; II - for proferida por juiz impedido ou por juízo absolutamente incompetente; III - resultar de dolo ou coação da parte vencedora em detrimento da parte vencida ou, ainda, de simulação ou colusão entre as partes, a fim de fraudar a lei; IV - ofender a coisa julgada; V - violar manifestamente norma jurídica; VI - for fundada em prova cuja falsidade tenha sido apurada em processo criminal ou venha a ser demonstrada na própria ação rescisória; VII - obtiver o autor, posteriormente ao trânsito em julgado, prova nova cuja existência ignorava ou de que não pôde fazer uso, capaz, por si só, de lhe assegurar pronunciamento favorável; VIII - for fundada em erro de fato verificável do exame dos autos. $\int 1^{\circ}$ Há erro de fato quando a decisão rescindenda admitir fato inexistente ou quando considerar inexistente fato efetivamente ocorrido, sendo indispensável, em ambos os casos, que o fato não represente ponto controvertido sobre o qual o juiz deveria ter se pronunciado. $\int 2^{\circ}$ Nas hipóteses previstas nos incisos do caput, será rescindível a decisão transitada em julgado que, embora não seja de mérito, impeça: I - nova propositura da demanda; ou II - admissibilidade do recurso correspondente. $\int 3^{\circ} \mathrm{A}$ ação rescisória pode ter por objeto apenas 1 (um) capítulo da decisão. $\int 4^{\circ}$ Os atos de disposição de direitos, praticados pelas partes ou por outros participantes do processo e homologados pelo juízo, bem como os atos homologatórios praticados no curso da execução, estão sujeitos à anulação, nos termos da lei. $\int 5^{\circ}$ Cabe ação rescisória, com fundamento no inciso $\mathrm{V}$ do caput deste artigo, contra decisão baseada em enunciado de súmula ou acórdão proferido em julgamento de casos repetitivos que não tenha considerado a existência de distinção entre a questão discutida no processo e o padrão decisório que lhe deu fundamento. $\int 6^{\circ}$ Quando a ação rescisória fundar-se na hipótese do $\int 5^{\circ}$ deste artigo, caberá ao autor, sob pena de inépcia, demonstrar, fundamentadamente, tratar-se de situação particularizada por hipótese fática distinta ou de questão jurídica não examinada, a impor outra solução jurídica”. (grifos no original)

Verifica-se, portanto, que a ação rescisória no Direito Eleitoral difere daquela prevista no Processo Civil, notadamente pelo fato de que a decisão rescindenda deve tratar da ocorrência de uma hipótese de inelegibilidade, além dos fatos insertados no art. 966, sob pena de não conhecimento. 


\section{COMPETÊNCIA}

Como já dito, as únicas decisões rescindíveis são aquelas onde a coisa julgada se formou no âmbito do TSE.

Eis a lição de José Jairo Gomes (2016, p. 255/256):

A citada alínea j, I, art. 22 do CE atribuiu competência rescisória tão somente ao TSE, de sorte que, diante da expressa previsão legal e da incidência do princípio da especialidade, os tribunais regionais eleitorais não detêm competência para processar e julgar a ação em tela, nem mesmo perante de seus próprios julgados.

Em outras palavras, somente é possível a Corte Superior apreciar rescisória de seus próprios julgados, seja por força de sua competência originária ou mesmo recursal, não sendo cabível ação rescisória perante os juízes e tribunais regionais eleitorais ${ }^{7}$.

Nessa linha de raciocínio, estão os ensinamentos de Carlos Mário da Silva Velloso e Walber de Moura Agra (2016, p. 452):

A competência para julgar Ação Rescisória pertence ao Tribunal Superior Eleitoral, sem possibilidade de sua impetração perante outra instância judicial (art. 22, I, j, do CE c/c os arts. 102, I, j, e 105, I, e, da CF). Realizando-se a res judicata na esfera monocrática ou concernente a decisões dos Tribunais Regionais Eleitorais, tem-se como impossível a impetração de ação rescisória. Com isso, não se pretende afirmar que as decisões de primeira e segunda instâncias tenham mais força normativa que as decisões do Tribunal Superior Eleitoral. Apenas, deixou-se essa competência somente com o Tribunal Superior Eleitoral para que ele pudesse balizar os casos para garantir maior segurança jurídica. (grifos no original)

Não se deve olvidar, ainda, que é possível a propositura de ação rescisória contra decisões monocráticas proferidas no âmbito do Tribunal

\footnotetext{
7 AGRAVO REGIMENTAL. AÇÃO RESCISÓRIA. DECISÃO DE JUIZ ELEITORAL. IMPOSSIBILIDADE. 1. A ação rescisória somente é cabível no âmbito da Justiça Eleitoral para desconstituir decisão deste c. Tribunal Superior que contenha declaração de inelegibilidade. Não compete a este e. Tribunal, portanto, o conhecimento de ação rescisória contra decisões proferidas pelos tribunais regionais ou por juízes de primeiro grau. 2. Agravo regimental não provido. (TSE, AR 262/SP, Rel. Min. Felix Fischer, j. em 22.04.2008, DJe de 06.05.2008).
} 
Superior Eleitoral ${ }^{8}$, desde que apreciem o mérito recursal, visto que não há necessidade de que as partes esgotem todos os recursos cabíveis para intentar ação rescisória, nos moldes da Súmula n. ${ }^{\circ} 514$ do STF, in verbis: "Admite-se ação rescisória contra sentença transitada em julgado, ainda que contra ela não se tenha esgotado todos os recursos".

\section{PRAZO DE AJUIZAMENTO}

O prazo para ajuizamento da ação rescisória eleitoral é de 120 (cento e vinte) dias, a contar do trânsito em julgado da decisão que declarou ou reconheceu a inelegibilidade, conforme dispõe o art. 22, inciso I, alínea “j”, do Código Eleitoral. Entende-se, ainda, que tal prazo não é de prescrição, mas de decadência, não se submetendo a motivos de suspensão ou interrupção.

Nesse sentido, está a lição de Rodrigo Lopez Zilio (2016, p. 655):

A ação rescisória deve ser ajuizada no prazo de 120 dias, contados da decisão irrecorrível. Trata-se de prazo decadencial e preclusivo. Por decisão irrecorrível se entende aquela proferida em outros autos e que reconheceu a inelegibilidade, em juízo de mérito, sem a possibilidade de qualquer irresignação recursal.

${ }^{8}$ AÇÃO RESCISÓRIA. INELEGIBILIDADE. ART. 1º, I, g, DA LC N. ${ }^{\circ} 64 / 90$. REJEIÇÃO DE CONTAS. TCU. CONVÊNIO FEDERAL. REGISTRO DE CANDIDATURA INDEFERIDO. DECISÃO MONOCRÁTICA. VIOLAÇÃO LITERAL A DISPOSITIVO DE LEI. ART. 16 DA CONSTITUIÇÃO FEDERAL. PRINCÍPIO DA ANTERIORIDADE ELEITORAL. LC N. ${ }^{\circ}$ 135/2010. ELEIÇÕES 2010. NÃO APLICAÇÃO. PRECEDETENTE STF. REPERCUSSÃO GERAL. AÇÃO JULGADA PROCEDENTE. REGISTRO DEFERIDO. 1. É admissível a propositura de ação rescisória contra decisão singular lavrada por membro desta Corte, desde que apreciado o mérito da causa pelo ministro relator. 2. O STF decidiu, por maioria, que a LC n. ${ }^{\circ} 135$ não se aplica às eleições 2010, em face do princípio da anterioridade eleitoral (art. 16 da CF/88), reconhecendo a repercussão geral da questão (RE n. ${ }^{\circ}$ 633.703/ MG, rel. Min. Gilmar Mendes, sessão plenária de 23.3.2011). 3. Afastada a incidência da LC n. ${ }^{\circ}$ 135/2010, a decisão proferida no RO n. ${ }^{\circ} 2263-12 /$ BA deve ser rescindida, pois, nos termos da redação anterior do art. $1^{\circ}$, I, g, da LC n. ${ }^{\circ} 64 / 90$, o prazo de inelegibilidade é de 5 (cinco) anos, contados a partir da data da decisão irrecorrível do órgão competente. 4. No caso vertente, o julgamento das contas pelo TCU ocorreu em 28.8.2001, por meio do Acórdão n. ${ }^{\circ}$ 529/2001, cujo trânsito em julgado se deu no dia 21.12.2002, já tendo transcorrido, portanto, em 21.12.2007, o prazo de Inelegibilidade previsto na mencionada norma. 5. Ação rescisória que se julga procedente para deferir-se o pedido de registro de candidatura de Joélcio Martins da Silva ao cargo de deputado estadual. (TSE, AR 64621/ BA, Rel. Min. Marcelo Henriques Ribeiro de Oliveira, j. em 26.05.2011, DJe de 22.08.2011). 
Esse é o entendimento pacificado nos Tribunais Superiores, objeto inclusive do enunciado da Súmula 401 do STJ, que assim preconiza: "O prazo decadencial da ação rescisória só se inicia quando não for cabível qualquer recurso do último pronunciamento judicial".

Por outro lado, diante da previsão expressa contida na esfera eleitoral, verifica-se que o transcurso de 2 (dois) anos previsto no artigo 975 do Novo Código de Processo Civil não se aplica à espécie, como se pode inferir da lição de Roberto Moreira de Almeida (2017, p. 646): "Não se deve utilizar o prazo bienal, tal qual previsto no art. 975 do Código de Processo Civil, mas sim o lapso temporal de 120 (cento e vinte) dias, a contar do trânsito em julgado da decisão atacada, conforme estabelecido pela LC n. ${ }^{\circ}$ 86/96”.

\section{LEGITIMIDADE E PROCEDIMENTO}

A legitimidade ativa para a propositura da ação rescisória cabe ao cidadão que teve sua inelegibilidade reconhecida, ao partido político ou coligação pela qual fora eleito, como terceiro interessado, e ao Ministério Público com fins de proteger os interesses difusos da sociedade e do regime democrático.

Já a legitimidade passiva pertence aquele que moveu a ação que redundou na declaração de inelegibilidade do titular da rescisória.

No mesmo sentido, Rodrigo Lopez Zilio (2016, p. 656/657) aduz:

A legitimidade ativa para propositura da ação rescisória é daquele que teve a decisão de inelegibilidade proferida contra si. [...]

No entanto, visualiza-se legitimidade do partido político em manusear a rescisória eleitoral, já que nítido o interesse em buscar a integridade do gozo dos direitos políticos de pessoa formalmente vinculada à agremiação. De outra, parte em face ao caráter de transitoriedade, não se evidencia legitimidade para coligação partidária aforar a ação rescisória na esfera especializada. O Ministério Público Eleitoral também possui legitimidade ativa para esgrimar ação rescisória, pois, como fiscal da lei, tem interesse na preservação da elegibilidade de determinado cidadão quando houver decisão que ilegitimamente decrete sua inelegibilidade. Embora se trate de ação que visa afastar restrição de caráter pessoal - que é a inelegibilidade -, o interesse ministerial no aforamento da rescisória se esteia no desiderato de preservação da integridade de direitos 
políticos de quem possui plenitude do gozo e na atribuição de defesa da ordem e do regime democrático. Somente haverá a plena preservação do regime democrático na exata proporção em que assegurados, com maior amplitude possível, os direitos políticos dos jurisdicionados que efetivamente ostentem o direito subjetivo de manutenção da integralidade do seu status político. Contudo, em sendo a inelegibilidade pretendida rescindir oriunda de processo aforado originariamente pelo Ministério Público, inexiste interesse do órgão ministerial para propor a ação rescisória.

A legitimidade passiva é daquele que ajuizou a ação que resultou do reconhecimento da inelegibilidade que é pretendida rescindir. (grifos no original)

Noutro giro, cumpre salientar que o rito adotado para o procedimento da ação rescisória eleitoral é o ordinário, obedecendo apenas no que for compatível com a seara eleitoral os mandamentos insculpidos no art. 966 e seguintes do Novo Código de Processo Civil, notadamente pela gratuidade e especificidade dos atos eleitorais, a dispensar o autor de custas processuais e do depósito de 5\% (cinco por cento) sobre o valor da causa, a título de multa, estatuída no art. 968, inciso II, do NCPC.

Por oportuno, trago à lição de Flávio Cheim Jorge (2016, p. 682) acerca da questão:

A única referência à Ação Rescisória no Direito Eleitoral encontrase na alínea "j” ao art. 22, I, do Código Eleitoral. Nenhuma outra previsão ou disposição na legislação eleitoral existe a respeito desse demanda.

Isso faz com que, naturalmente, o Código de Processo Civil seja o repertório de normas a ser utilizado subsidiariamente ao trâmite desse demanda, naquilo que não houver norma em sentido contrário ou mesmo existir incompatibilidade entre os sistemas eleitoral e civil. Assim, há que se aplicar o procedimento previsto no CPC, sem, contudo, deixar de observar que na rescisória eleitoral deverá adotada regra específica para a legitimidade ativa (como nas demais ações eleitorais); o prazo para ajuizamento é de 120 dias; seu cabimento encontra-se vinculado "aos casos de inelegibilidade"; não deve ser exigido o depósito de 5\% (cinco por cento) sobre valor da causa.

Destarte, por conta da ausência de previsão legal expressa no âmbito da Justiça Especializada, convém adotar por analogia, o procedimento da 
ação rescisória disposto no Novo Código de Processo Civil, conforme os ditames de seu artigo 15, in verbis: "na ausência de normas que regulem processos eleitorais, trabalhistas ou administrativos, as disposições deste Código lhes serão aplicadas supletiva e subsidiariamente”.

Frisa-se, ainda, no que tange as peculiaridades da ação rescisória eleitoral, que é admissível a concessão da tutela antecipada em situações teratológicas, reveladoras de dano de grave e impossível reparação, bem como em ocasiões que comprometam todo o processo eleitoral ${ }^{9}$.

Por último, no que urge a possibilidade de ajuizamento de uma ação rescisória contra decisão que julgou anterior ação rescisória, apesar de inexistir até o momento caso semelhante analisado pelo TSE, é juridicamente viável.

\section{Segundo Fredie Didier Jr. e Leonardo Carneiro da Cunha (2016, p. 421):}

Cabe rescisória de rescisória, por exemplo, se se demonstrar a corrupção, prevaricação, concussão ou impedimento de um dos juízes que julgaram a primeira ação rescisória, ou a incompetência absoluta do tribunal que julgou a ação rescisória. Nesse sentido, com precisão, o enunciado n. ${ }^{\circ} 400$ da súmula do TST: "Em se tratando de rescisória de rescisória, o vício apontado deve nascer na decisão rescindenda, não se admitindo a rediscussão do acerto do julgamento da rescisória anterior. Assim, não se admite rescisória calcada no inciso $\mathrm{V}$ do art. 485 do CPC para discussão, por má aplicação dos mesmos dispositivos de lei, tidos por violados na rescisória anterior, bem como para arguição de questões inerentes à ação rescisória primitiva". A referência ao art. 485 do CPC-1973 deve ser compreendida como se feita ao art. 966 do CPC-2015. (grifos no original)

Já para Rogério Carlos Born (2003, p. 80):

...o julgamento da rescisória das rescisórias, ou seja, das ações rescisórias promovidas contra as sentenças proferidas em outras

\footnotetext{
9 Ação rescisória - Questão de ordem - Tutela antecipada - Concessão - Impossibilidade, ressalvados casos excepcionais. Não é admissível a concessão de tutela antecipada em ação rescisória na Justiça Eleitoral, salvo em situações teratológicas que causam dano grave e evidente, de impossível reparação, ou nos casos em que pode ser comprometido o processo eleitoral como um todo. (TSE, AR 60/PE, Rel. Min. Fernando Neves da Silva, j. em 05.09.2000, DJe de 05/06/2001)
} 
ações rescisórias é tecnicamente possível, mas somente pelo próprio Tribunal Superior Eleitoral, pois conforme discorremos alhures, a competência do Supremo Tribunal Federal é exclusiva para rescisão dos próprios julgados.

Em verdade, a doutrina majoritária e o sistema processual vigente autorizam a tese da rescisória de rescisória, desde que haja um dos vícios previstos no rol taxativo, disposto no art. 966 do NCPC.

\section{CONCLUSÕES}

A ação rescisória eleitoral é um importante instrumento de impugnação à coisa julgada que se formou no âmbito do Tribunal Superior Eleitoral quando o aresto objurgado contenha decretação de inelegibilidade e esteja eivado de ostensivas vicissitudes.

Ademais, a decisão para ser rescindida deve obedecer três pressupostos. O primeiro pressuposto é o julgamento de mérito oriundo do TSE e que tenha reconhecido qualquer das causas de inelegibilidade. O segundo pressuposto é a verificação de uma das hipóteses do artigo 966 do NCPC, especialmente as arroladas de maneira taxativa em seus oito incisos. O terceiro pressuposto da ação rescisória eleitoral é a observância do prazo decadencial e preclusivo de 120 (cento e vinte) dias, pois, ainda que eivado de ilegalidades, o processo tem também como escopo a estabilização das relações jurídicas, razão pela qual não se pode admitir um prazo indeterminado de impugnação à coisa julgada, ainda mais considerando o fenômeno da temporariedade do mandato eletivo e da celeridade do Direito Eleitoral. Destarte, decorrido o prazo decadencial da ação rescisória, todos os vícios ficam sanados, formando-se a chamada coisa soberanamente julgada.

Daí salientar que, por ser uma medida excepcionalíssima destinada a desconstituir decisão judicial eleitoral transitada em julgado, a ação rescisória somente é cabível nas hipóteses legais, qual sejam declaração definitiva de inelegibilidade de pretenso candidato e ocorrência de um dos fatos narrados no art. 966 do NCPC.

Observa-se ainda, dada ausência de previsão legal expressa, que deve ser adotado somente no que couber e for compatível com a seara eleitoral o procedimento da ação rescisória insertado no art. 968 e seguintes do Novo Código de Processo Civil. 
Por fim, infere-se que é juridicamente possível o ajuizamento de uma ação rescisória contra decisão que julgou anterior ação rescisória nas hipóteses de corrupção, prevaricação, concussão ou impedimento de um dos magistrados que julgaram a causa inaugural, não obstante inexistir caso semelhante analisado pela Suprema Corte Eleitoral.

\section{REFERÊNCIAS}

AGRA, Walber de Moura. Manual prático de direito eleitoral. Belo Horizonte: Fórum, 2016.

ALMEIDA, Roberto Moreira de. Curso de Direito Eleitoral. 11 ed. Salvador: Juspodivm, 2017.

BORN, Rogério Carlos. Ação Rescisória no direito eleitoral. Curitiba: Juruá, 2003.

BRASIL. Senado Federal. Projeto de Lei Complementarn. ${ }^{\circ} 134$ de 2012, que altera os arts. 22, I, j, e acrescenta a alínea h ao art. 29, I, e o Título III à Parte Quinta da Lei n. ${ }^{\circ}$ 4.737, de 15 de julho de 1965 - Código Eleitoral, para tratar da Ação Rescisória Eleitoral. Autor: Sérgio Souza. Disponível em: <http://www25.senado.leg. br/web/atividade/materias>. Acesso em: 06 maio 2017.

. Tribunal Regional Eleitoral do Rio de Janeiro. Recurso Eleitoral n. ${ }^{\circ}$ 4654, Acórdão de 29.09.2016. Relator Desembargador Marco José Mattos Couto. Diário de Justiça Eletrônico. Rio de Janeiro, 07 outubro 2016. Disponível em: <http://www.tse.jus.br/jurisprudencia/pesquisa-de-jurisprudencia/ jurisprudencia $>$. Acesso em: 11 junho 2017.

- Tribunal Superior Eleitoral. Agravo Regimental em Ação Rescisória n. ${ }^{\circ}$ 54253, Acórdão de 09.03.2017. Relator Ministro Napoleão Nunes Maia Filho. Diário de Justiça Eletrônico. Brasília, 30 março 2017. Disponível em: <http://www.tse.jus.br/jurisprudencia/pesquisa-dejurisprudencia/jurisprudencia>. Acesso em: 14 junho 2017.

- Tribunal Superior Eleitoral. Agravo Regimental em Ação Rescisória n. ${ }^{\circ}$ 179722, Acórdão de 04.09.2012. Relator Ministro José Antônio Dias Toffoli. Diário de Justiça Eletrônico. Brasília, 24 setembro 2012. Disponível em: <http://www.tse.jus.br/jurisprudencia/pesquisa-de-jurisprudencia/ jurisprudencia $>$. Acesso em: 22 maio 2017. 
. Tribunal Superior Eleitoral. Ação Rescisória n. ${ }^{\circ}$ 52840, Acórdão de 17.11.2015. Relator Ministro Luiz Fux. Diário de Justiça Eletrônico. Brasília, 13 junho 2016. Disponível em: <http://www.tse.jus.br/jurisprudencia/ pesquisa-de-jurisprudencia/jurisprudencia > . Acesso em: 03 junho 2017.

- Tribunal Superior Eleitoral. Agravo Regimental em Ação Rescisória n. ${ }^{\circ}$ 16927, Acórdão de 06.08.2013. Relator Ministro José de Castro Meira. Diário de Justiça Eletrônico. Brasília, 28 agosto 2013. Disponível em: <http://www.tse.jus.br/jurisprudencia/pesquisa-de-jurisprudencia/ jurisprudencia $>$. Acesso em: 28 maio 2017.

. Tribunal Superior Eleitoral. Ação Rescisória n. ${ }^{\circ} 295294$, Acórdão de 06.10.2010. Relator Ministro Arnaldo Versiani Leite Soares. Diário de Justiça Eletrônico. Brasília, 12 novembro 2010. Disponível em: <http://www. tse.jus.br/jurisprudencia/pesquisa-de-jurisprudencia/jurisprudencia $>$. Acesso em: 22 maio 2017.

- Tribunal Superior Eleitoral. Agravo Regimental em Ação Rescisória n. ${ }^{\circ}$ 31852, Acórdão de 16.06.2016. Relator Ministro Luiz Fux. Diário de Justiça Eletrônico. Brasília, 26 agosto 2016. Disponível em: <http://www.tse.jus.br/jurisprudencia/pesquisa-de-jurisprudencia/ jurisprudencia $>$. Acesso em: 03 junho 2017.

- Tribunal Superior Eleitoral. Agravo Regimental em Ação Rescisória n. ${ }^{\circ}$ 262, Acórdão de 22.04.2008. Relator Ministro Felix Fisher. Diário de Justiça Eletrônico. Brasília, 06 maio 2008. Disponível em: < http:/ /www.tse. jus.br/jurisprudencia/pesquisa-de-jurisprudencia/jurisprudencia $>$. Acesso em: 23 maio 2017.

. Tribunal Superior Eleitoral. Ação Rescisória n. ${ }^{\circ}$ 64621, Acórdão de 26.05.2011. Relator Ministro Marcelo Henriques Ribeiro de Oliveira. Diário de Justiça Eletrônico. Brasília, 22 agosto 2011. Disponível em: <http://www. tse.jus.br/jurisprudencia/pesquisa-de-jurisprudencia/jurisprudencia $>$. Acesso em: 23 maio 2017.

DIDIER JÚNIOR, Fredie; CUNHA, Leonardo Carneiro da. Curso de direito processual civil: o processo civil nos tribunais, recursos, ações de competência originária de tribunal. 13 ed. Salvador: Juspodivm, 2016.

GOMES, José Jairo. Recursos eleitorais. 2 ed. São Paulo: Atlas, 2016. 
JORGE, Flávio Cheim; LIBERATO, Ludgero; RODRIGUES, Marcelo Abelha. Curso de Direito Eleitoral. Salvador: Juspodivm, 2016.

MEDEIROS, Marcílio Nunes. Legislação eleitoral comentada e anotada. Salvador: Juspodivm, 2017.

NETO, Jaime Barreiros. Coleção Sinopse para concursos: Direito Eleitoral. 6 ed. Salvador: Juspodivm, 2016.

NIESS, Pedro Henrique Távora; NIESS DE SOUZA, Luciana Toledo Távora; NIESS KAHN, Andréa Patrícia Toledo Távora. Direito Eleitoral. São Paulo: Edipro, 2016.

VELLOSO, Carlos Mário da Silva; AGRA, Walber de Moura. Elementos de direito eleitoral. 5 ed. São Paulo: Saraiva, 2016.

ZILIO, Rodrigo López. Direito Eleitoral. 5 ed. Porto Alegre: Verbo Jurídico, 2016. 